\title{
ABC - Analysis, as an Important Tool for Generating an Optimal Assortment Plan Commercial Enterprises
}

\author{
Shabanova L.B. \\ Kazan Institute (branch), "Russian Economic University" named after, \\ G.V. Plekhanov, Kazan, 420111, Russia \\ Bagautdinova N.G. \\ Kazan Federal University, Institute of Management, Economics and Finance, Kazan, 420008, Russia \\ Gafurov I.R. \\ Kazan Federal University, Institute of Management, Economics and Finance, Kazan, 420008, Russia \\ Salimov L.N. \\ Institute of Economics, Management \& Law (Russia, Kazan), Kazan, 420108, Russia
}

\section{Doi:10.5901/mjss.2015.v6n3p691}

\begin{abstract}
High rates of financial and economic state trading enterprise is largely dependent on its assortment policy. It is known that not all commodity groups food supermarket are equally profitable. Since the formation of a range of tactical problems of commercial enterprise, the analysis of its economic efficiency should be evaluated systematically. The most popular method of assessment of such acts $A B C$ - analysis. The purpose of the $A B C$-analysis in our study - Identification of product groups, with the most high, medium and low share of sales.

Keywords: Trade policy, the assortment plan, methods, graphical methods, the definition of boundaries, grouping objects of management.
\end{abstract}

\section{Introduction}

Optimal assortment policy of commercial enterprise is manifested through the assortment plan. Assortment Plan is a list of product categories and headings on the sale of the company which specializes. The plan has the following characteristics: the breadth of product lines (the number of product groups), depth of product lines (the number of headings in each commodity group), saturation (number of product categories and headings in the plan). Due to the fact that the commodity groups and headings have different margin necessary to optimize the assortment plan. For this purpose we use a technique ABC - analysis. Marketing analysis of enterprises in Russia, assessment of the role of consumer spending in ensuring the dynamics of the Russian economy, as well as study models the interaction of firms and components of the environment in Russia has a particular organization $[1,2,6]$.

\section{Method}

Method ABC - analysis is widely used on the Russian trading companies. This is a graphical method for determining the boundaries between groups of products $A, B$ and $C$. On the $x$-axis are postponed headings arrayed in descending order of their share in total sales. Along the $\mathrm{Y}$-axis deferred sales share in total sales, calculated on an accrual basis and expressed as a percentage. Under current conditions, this method is widely used $[3,4,5]$.

\section{Result}

For analysis, the following data were used: 
- $\quad$ supermarket sales for the quarter of the year;

- the range presented in the form of commodity groups;

- revenue for each product - is calculated by multiplying the price of the goods on his sales for the quarter. revenue $=$ sales_volume $*$ price $(1$.)

- he share of each commodity group in the total range - calculated by the ratio of revenue to the commodity group's total revenue of all product groups..

share_of_revenuebby_product $=\frac{\text { revenue_by_product }}{\text { total_revenue }} * 100 \%$

Following the results of calculations of the best selling and highest revenue-bearing products, will be located in the blocks "A" and "B".

Thus, the entire range of supermarket for the reporting quarter of the year was divided into product groups, the total amount of 41 . analysis.

Using the formula mentioned earlier, we have obtained the original data (see. Table 1) needed for the ABC

Table 1. Initial data for $A B C$-analysis

\begin{tabular}{|c|c|c|c|c|c|}
\hline Sl. No & Assortment position & $\begin{array}{c}\text { Revenue, } \\
\text { thous. roubles }\end{array}$ & $\begin{array}{c}\text { Specific weight sales } \\
\text { volume, } \%\end{array}$ & $\begin{array}{l}\text { Share in the turnover on an } \\
\text { accrual basis, } \%\end{array}$ & Classification \\
\hline 1. & Wine beverages & 73692 & 26,30 & 26,3 & \multirow{11}{*}{ A } \\
\hline 2. & Meat \& sausage products & 54440 & 19,45 & 45,75 & \\
\hline 3. & Semi-finished products & 16213 & 5,76 & 51,51 & \\
\hline 4. & The low-alcohol products & 15642 & 5,50 & 57,01 & \\
\hline 5. & Cheese & 14436 & 5,15 & 62,16 & \\
\hline 6. & Vegetable oils & 11472 & 4,09 & 66,22 & \\
\hline 7. & Baking products & 10070 & 3,59 & 69,81 & \\
\hline 8. & Milk production & 9634 & 3,44 & 73,25 & \\
\hline 9. & Baby Food & 9211 & 3,29 & 76,54 & \\
\hline 10. & Confectionery & 8246 & 2,94 & 79,48 & \\
\hline 11. & Pasta & 6800 & 2,42 & 81,9 & \\
\hline 12. & Means for washing \& cleaning & 4902 & 1,75 & 83,65 & \multirow{10}{*}{ B } \\
\hline 13. & Personal hygiene items & 4367 & 1,56 & 85,21 & \\
\hline 14. & Groats & 3841 & 1,37 & 86,58 & \\
\hline 15. & Juices & 3786 & 1,35 & 87,93 & \\
\hline 16. & Frozen products & 3786 & 1,35 & 89,28 & \\
\hline 17. & Non-alcoholic beverages & 3280 & 1,17 & 90,45 & \\
\hline 18. & Fishery products & 3163 & 1,13 & 91,58 & \\
\hline 19. & Canned Fish & 3163 & 1,13 & 92,71 & \\
\hline 20. & Tobacco & 2500 & 0,89 & 93,6 & \\
\hline 21. & Meat Canned & 2324 & 0,83 & 94,43 & \\
\hline 22. & Chips \& Snacks & 2324 & 0,83 & 95,26 & \multirow{21}{*}{ C } \\
\hline 23. & Own pastries & 1757 & 0,62 & 95,88 & \\
\hline 24. & Flour & 1500 & 0,54 & 96,42 & \\
\hline 25. & Tea & 1411 & 0,50 & 96,92 & \\
\hline 26. & Coffee & 1333 & 0,47 & 97,39 & \\
\hline 27. & Vegetables \& fruits & 1088 & 0,38 & 97,77 & \\
\hline 28. & Olive oil & 951 & 0,34 & 98,11 & \\
\hline 29. & Stationery & 951 & 0,34 & 98,45 & \\
\hline 30. & Salt & 614 & 0,22 & 98,67 & \\
\hline 31. & Matches & 512 & 0,18 & 98,85 & \\
\hline 32. & Utensils & 512 & 0,18 & 99,03 & \\
\hline 33. & Eggs & 512 & 0,18 & 99,2 & \\
\hline 34. & Sugar & 495 & 0,17 & 99,37 & \\
\hline 35. & Perfume & 241 & 0,08 & 99,45 & \\
\hline 36. & Salads & 186 & 0,06 & 99,51 & \\
\hline 37. & Kitchenware & 145 & 0,05 & 99,56 & \\
\hline 38. & Toys & 110 & 0,04 & 99,6 & \\
\hline 39. & Sauces \& spices & 111 & 0,03 & 99,63 & \\
\hline 40. & Margarine products & 111 & 0,03 & 99,66 & \\
\hline 41. & Goods for animals & 14 & 0,005 & 99,665 & \\
\hline In total & & 279.846 & 99,665 & 99,665 & \\
\hline
\end{tabular}


Using the data in Table 1 we construct a curve Lorentz concentration, where the x-axis are arranged product groups, in descending order of their share in total sales, and the vertical axis - the size of turnover. Border blocks "A", "B" and "C" was determined by the tangent to the curve analysis (see. Figure. 1).

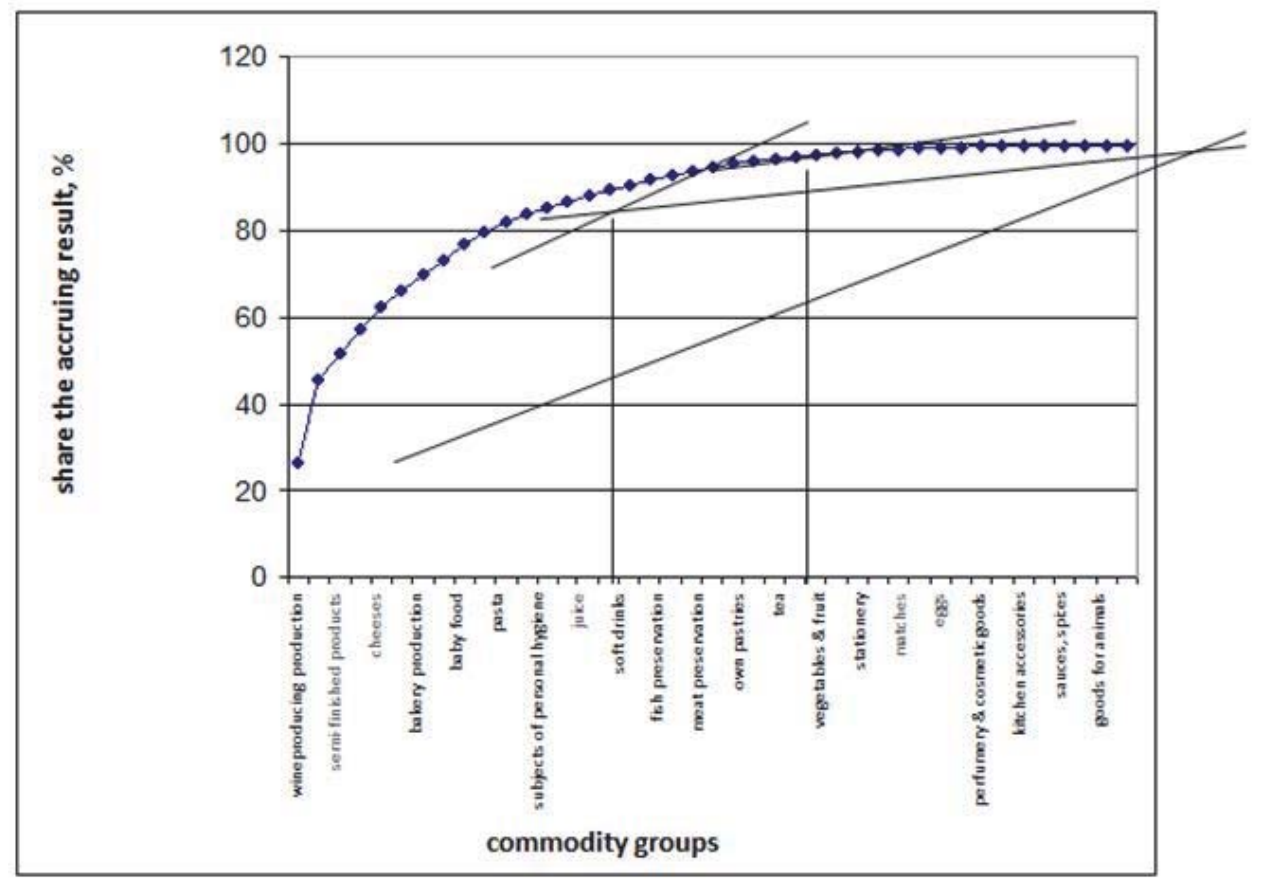

Figure. 1. ABC analysis supermarket "Perekrestok" in the reporting quarter of the year

\section{Conclusion}

The obtained results allow us to conclude that the most advantageous from an economic point of view for the supermarket "Perekrestok" is the sale of the first 11 product groups on the list in Table 1. - These goods included in the block "A".

The block "B" are 9 product groups. Do not forget that they are also beneficial to the commercial enterprise, but the return they gain less than the profits from the sale of goods Block "A".

In the block "C" includes all remaining items in Table 1. Note that they account for almost $50 \%$ of the total range of the supermarket. These products are not economically viable to implement. However, to give them a supermarket can not, as many of them are necessary for the buyers who come just for this group of products. All hopes seller focused on the fact that purchase goods from the commodity group " $\mathrm{C}$ ", the buyer will make a number of acquisitions of goods from the block "A" or "B».

\section{References}

Bagautdinova N.G., Safiullin L.N., Minnahmetov R.R. Institutionalization of Firm Environment in Conditions of Growing Turbulence // Mediterranean Journal of Social Sciences, 2014. Volume 5, No 12, pp. 55-58.

Handanhal Ravinder, Ram B. Misra. ABC Analysis For Inventory Management: Bridging The Gap Between Research and Classroom // American Journal Of Business Education - Third Quarter 2014 Volume 7, No 3. pp. 257-263.

M. Karthick, S. Karthikeyan, M.C. Pravin. A Model for Managing and Controlling the Inventory of Stores Items based on ABC Analysis // Global Journal of Researches in Engineering: Industrial Engineering. Volume 14, Issue 2, Version 1.0, 2014. pp. 1-6.

Bagautdinova N.G., Safiullin L.N., Badrtdinov N.N. The Role of Consumer Expenses in Ensuring Forward Dynamics of The Russian Economy // Mediterranean Journal of Social Sciences, 2014. Volume 5, No 12, pp. 43-48.

Mohammad Reza Motadel, Abbas Toloie Eshlagy, Sarvenaz Ghasemi. The Presentation of a Mathematical Model to Assess and Control the Inventory Control System through ABC Analysis Approach (A Case Study of Lino Meat Products Company) // International Journal of Information, Security and Systems Management, 2012, Vol. 1, No. 1, pp. 1-13.

Safiullin M.R., Samigullin I.G., Safiullin L.N. Model of Management of Competitiveness of a Machine-building Complex // World Applied 
Sciences Journal 27 (Economics, Management and Finance), 2013, pp. 212-216.

Shigabieva A.M., Safiullin L.N., Mazitov V.M., Saipullaev U.A. Some methodological foundation of an innovation theory. Life Science Journal 2014; 11(6s): 388 - 391.

Ablaev I.M., Khovanskaya E.S. Essence and Economical Substance of Innovative Cluster in Territorially Localized Business System// Mediterranean Journal of Social Sciences.- Vol.5, No12, (2014)-pp.159 - 162.

Ismagilova G.N., Safiullin L.N., Novenkova A.Z., Safiullin N.Z. Prospects of small business in Tatarstan. Life Science Journal 2014; $11(6 s): 396-399$.

Ulesov D.N., Shigabieva A.M., Safiullin L.N., Shaidullin R.N. Essential features of small and medium business. Life Science Journal 2014; $11(6 s): 392-395$. 